\title{
Blood biochemical parameters and organ development of brown layers fed reduced dietary protein levels in two rearing systems
}

\author{
Eduardo de Faria Viana ${ }^{1, \star}$, Heloisa Helena de Carvalho Mello², Fabyola Barros Carvalho ${ }^{2}$, \\ Marcos Barcellos Café ${ }^{2}$, Nadja Susana Mogyca Leandro², \\ Emmanuel Arnhold ${ }^{2}$, and José Henrique Stringhini ${ }^{2}$
}

\author{
* Corresponding Author: \\ Eduardo de Faria Viana \\ Tel: +55-64-34651900, \\ E-mail: eduardo.viana@ifgoiano.edu.br \\ ${ }^{1}$ Federal Institute Goiano, GO, 75790-000, \\ Brazil \\ ${ }^{2}$ Department of Animal Science, Federal \\ University of Goiás, G0, 74690-900, Brazil \\ ORCID \\ Eduardo de Faria Viana \\ https://orcid.org/0000-0002-5729-5108 \\ Heloisa Helena de Carvalho Mello \\ https://orcid.org/0000-0002-0312-7424 \\ Fabyola Barros Carvalho \\ https://orcid.org/0000-0001-5900-5437 \\ Marcos Barcellos Café \\ https://orcid.org/0000-0002-1478-8009 \\ Nadja Susana Mogyca Leandro \\ https://orcid.org/0000-0002-6525-9975 \\ Emmanuel Arnhold \\ https://orcid.org/0000-0003-0922-146X \\ José Henrique Stringhini \\ https://orcid.org/0000-0002-3710-6963
}

Submitted Mar 27, 2021; Revised May 20, 2021; Accepted Jun 19, 2021
Objective: An experiment was conducted to evaluate the effect of different levels of crude protein $(\mathrm{CP})$ and two rearing systems (cage and floor), on blood parameters and digestive and reproductive organ development of brown laying hens.

Methods: A total of 400 Hisex Brown laying hens between 30 and 45 weeks of age were distributed in a completely randomized design and a $2 \times 4$ factorial arrangement, with main effects including two rearing systems (cage and floor) and levels of CP $(140,150,160$, and $180 \mathrm{~g} / \mathrm{kg}$ ), in a total of eight treatments and five replicates of 10 birds each with initial body weight of 1,877 $\mathrm{g}$ (laying hen in cage) and 1,866 $\mathrm{g}$ (laying hens in floor). The parameters evaluated were plasma total protein, albumin, uric acid, total cholesterol, relative weights of oviduct, abdominal fat, liver, gizzard, crest and dewlap, length of small intestine and oviduct.

Results: The blood parameters were similar in birds reared in cage and floor systems. The birds reared on the floor showed greater small intestine and oviduct weight (\%) and lower liver and pancreas weight (\%). A significant interaction was observed between factors for the relative gizzard, crest and dewlap weight, serum protein, uric acid, and total cholesterol $(\mathrm{p}<0.05)$. The diets with $140 \mathrm{~g} / \mathrm{kg} \mathrm{CP}$ resulted in lower serum protein and lower cholesterol in birds reared in floor system, while birds reared in cage system showed no effect of CP on both parameters. Birds reared in cage and fed with 140 and $150 \mathrm{~g} / \mathrm{kg} \mathrm{CP}$ presented lower uric acid. The group of birds reared in floor system fed $180 \mathrm{~g} / \mathrm{kg}$ had greater uric acid. Conclusion: The dietary protein level can be reduced up to $140 \mathrm{~g} / \mathrm{kg}$ for Hisex Brown hens (30 to 45 weeks of age) without an important effect on metabolic profile and organ development in both rearing systems.

Keywords: Blood Plasma; Digestive System; Poultry Housing; Protein Content; Welfare

\section{INTRODUCTION}

The rearing systems that allow laying hens to express their natural behaviors have been used to improve the hens welfare. Many countries have banned the use of conventional cages in laying hen production. The benefits of furnished and open systems are reduction of the prevalence of keel-bone fractures [1] and reduction of fearfulness [2]. Furthermore, the improvement of egg production and better egg internal and external quality $[3,4]$ has been related as the benefits of open systems, like a floor system. The eggs produced in conventional cages compared with those laid in free-range farming conditions, presented higher concentrations of total lipids, cholesterol, and gross energy [5]. It has been reported that eggs produced by birds in open systems present a higher yolk percentage compared to cage system $[3,6]$, and that the egg mineral content is affect by rearing system as well 
[7]. In this way, egg composition is affected by the system, therefore the blood parameters of laying hens that are related to egg formation could be affect too. Reducing space allowance in or eliminating access to a nest box results in disruption of biological function [8]. Based on this, the information about the metabolic and organ development effects in laying hens raised in alternative systems must be improved.

In addition to replacement of rearing system, poultry diets have been formulated based on the use of digestible amino acids, considering the ideal protein concept. It is reported that the reduction of dietary protein from $17 \%$ to $15.7 \%$ with amino acid supplementation is enough to maintain performance of Brown laying hens [9]. The rearing system affects both the performance of hens and the egg quality characteristics [10], that are associated to crude protein $(\mathrm{CP})$ requirements by birds. Therefore, the reduction of dietary protein should be studied in different rearing systems, to determine the rearing system affect the nutritional requirements of birds. According to de Almeida Brainer et al [11] hens housed in free-range systems have a greater $\mathrm{CP}$ requirement for maintenance than the $\mathrm{CP}$ requirement for production, due to its lower productive potential and greater caloric expenditure, given the physical activities that occur under semi-intensive management.

Blood biochemical parameters had been used as metabolic variables to assess the welfare of poultry [12]. The behavior, blood corticosterone and blood biochemical parameters in laying hens change during the stress $[13,14]$. The blood biochemical parameters provide information about immune system of birds, which is associated with environmental conditions, and can aid in the assessment of rearing systems. In addition, the digestive and reproductive organs development, and sexual characteristics (crest and dewlap) can be used to assess the birds' metabolism and development.

The biochemical composition of the blood plasma reflects the metabolic situation of the tissues, making it possible to evaluate changes in the organ's functions and the adaptation of the animal to nutritional and physiological challenges, in some cases, imposed by stressful situations [15]. Hens reared in floor systems are more challenged by microorganisms than those reared in cage systems. A trend toward increased birdto-bird transmission of Salmonella enteridis was detected in the aviary and floor system compared with the cage systems [16]. In fact, Parisi et al [17] showed that free-range eggs had higher prevalence of Salmonella and Campylobacter spp. than battery cage eggs, indicating a possible challenge to hens reared in floor system. In this context, the dietary protein requirements could be different in hens under different housing conditions as the protein participates of immune system in animals.

Due to these factors and considering that less is understood about the protein requirement for laying hens reared in a floor system, we hypothesized that the replacement from conventional cages to floor can change the protein requirements of the birds. In this context, it is important to undertake research focused on the serum biochemistryl and organ development of laying hens in floor and cage systems fed different dietary CP.

This study was conducted to investigate the blood biochemical parameters, the digestive and reproductive organs development of Hisex Brown layers, from 30th to 45th weeks of age in two rearing systems, receiving reduced dietary protein.

\section{MATERIALS AND METHODS}

\section{Animal care and study site}

This experiment was performed in accordance with Ethics Committee on the Use of Animals (CEUA/UFG), under protocol 312/11. The experiment was carried out in the city of Urutaí in the state of Goiás, Brazil, Latitude: $17^{\circ} 27^{\prime} 49^{\prime \prime} \mathrm{S}$, Longitude: $48^{\circ} 12^{\prime} 06^{\prime \prime} \mathrm{W}$, Altitude: $807 \mathrm{~m}$.

\section{Animals, experimental design, and management}

Four hundred Hisex Brown layers, from 30 to 45 weeks of age, were allotted in a completely randomized design and a $2 \times 4$ factorial arrangement, with main effects including two rearing systems (cage and floor) and four levels of CP (140, 150,160 , and $180 \mathrm{~g} / \mathrm{kg} \mathrm{CP}$ ), with five replicates of ten birds each with initial body weight of $1,877 \mathrm{~g}$ (laying hen in cage) and $1,866 \mathrm{~g}$ (laying hens in floor).

The experimental diets were isonutritive and formulated on the ideal protein concept, according to Rostagno et al [18] (Table 1).

The floor rearing system consisted of 20 boxes with rice hulls as a litter material. Each box was equipped with a pendular drinker, a linear tube feeder and a nest. The boxes had a measurement of $2.2 \times 1.5 \times 3 \mathrm{~m}$ (length $\times$ width $\times$ height) and the floor litter had a height of $10 \mathrm{~cm}$. The nest, built out of wood, had three holes $(33 \times 40 \times 45 \mathrm{~cm})$ and an elevation of $10 \mathrm{~cm}$ in relation to the litter line. The density of $3.3 \mathrm{~m}^{2} / \mathrm{bird}$ was adopted on the floor system. The conventional cages size was $100 \times 37 \times 40 \mathrm{~cm}$, with four divisions of $25 \mathrm{~cm}$. The density of $500 \mathrm{~cm}^{2} /$ bird in the cages was adopted. During the entire experimental period, ad libitum feed and water were provided and a lighting program with $16 \mathrm{~h}$ light and $8 \mathrm{~h}$ dark period, as indicated in the Hisex Brown Management Manual. The temperature inside the poultry houses were controlled with a maximum-minimum thermometer (Incoterm, Urutaí, GO, Brazil). The average of minimum and maximum temperature of cage system were $22.3^{\circ} \mathrm{C}$ and $30.1^{\circ} \mathrm{C}$, respectively. The average of minimum and maximum temperature of floor system were $22.5^{\circ} \mathrm{C}$ and $29.9^{\circ} \mathrm{C}$, respectively. 
Table 1. Composition of experimental diets

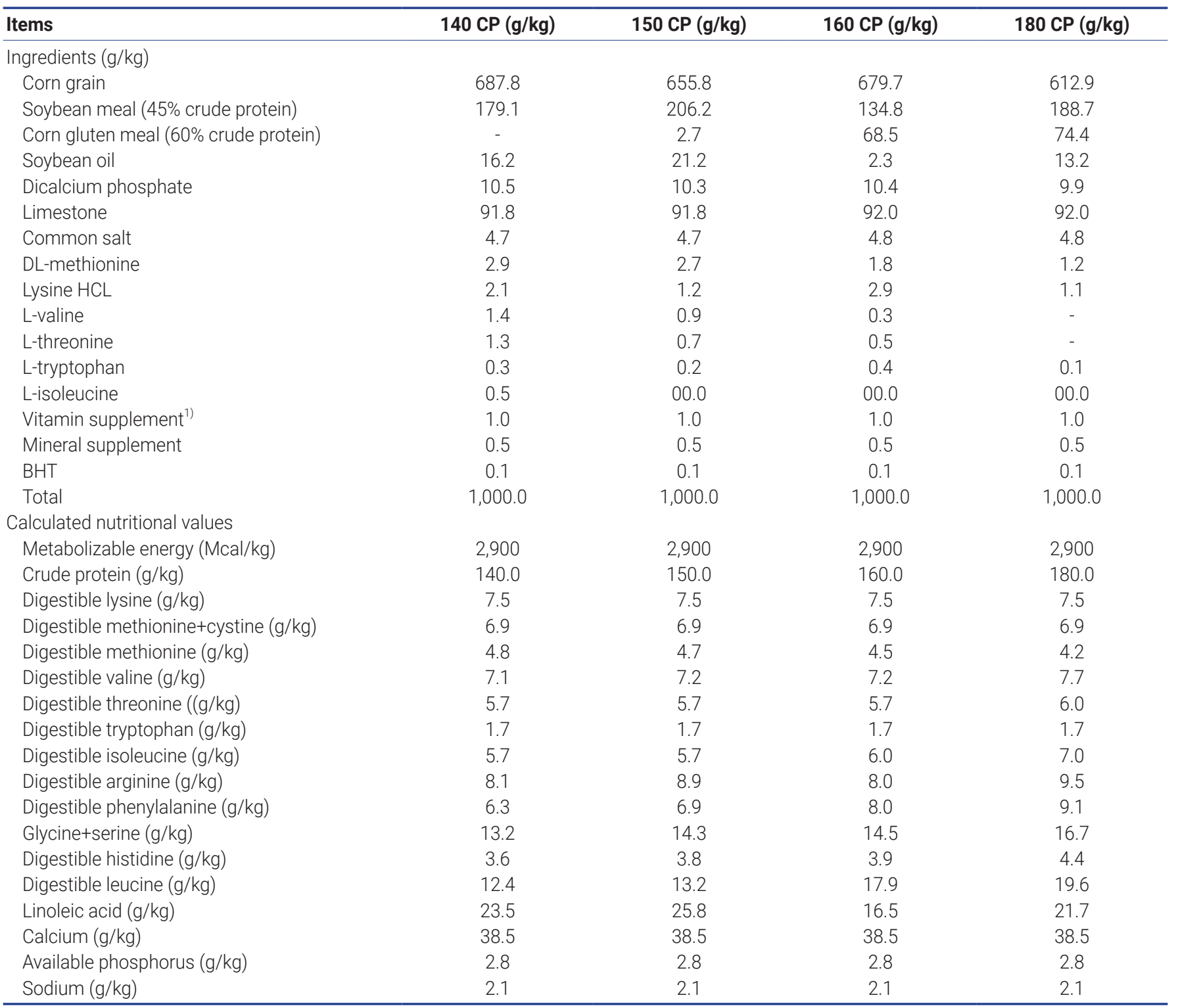

$\mathrm{CP}$, crude protein.

1) Supplementation levels (amount per kg of product): $10.000 \mathrm{IU}$ of Vit $\mathrm{A} ; 2.000 \mathrm{IU}$ of Vit $\mathrm{D}_{3} ; 1.833 \mathrm{mg}$ of Vit $\mathrm{E} ; 2 \mathrm{mg}$ of Vit $\mathrm{B}_{1} ; 1.000 \mathrm{mg}$ of vit $\mathrm{B}_{2} ; 3 \mathrm{mg}$ of $\mathrm{Vit}$ $\mathrm{B}_{6} ; 0.015 \mathrm{mg}$ vit $\mathrm{B}_{12} ; 12 \mathrm{mg}$ of pantothenic acid; $3 \mathrm{mg}$ of $V_{i t} \mathrm{~K}_{3} ; 1 \mathrm{mg}$ of folic acid; $0.25 \mathrm{mg}$ of selenium. $33.333 \mathrm{mg}$ of manganese; $6.567 \mathrm{mg}$ of iron; 2.667 $\mathrm{mg}$ of copper; $250 \mathrm{mg}$ of iodine; $26.667 \mathrm{mg}$ of Zinc; $6.000 \mathrm{mg}$ of Niacin; 70,000 mg of choline; $680 \mathrm{mg}$ of ethoxyquin; $8.333 \mathrm{mg}$ of halquinol.

\section{Blood sampling}

The blood parameters analysis was performed on the 2nd and 4th periods of egg production (37th and 45th weeks of age) and results were presented as mean of two periods.

After $6 \mathrm{~h}$ fasting, five hens from each treatment (one of each replication) at 37th and 45th weeks of age, totalizing ten birds per treatment, were selected to measure the blood parameters. About $5 \mathrm{~mL}$ of blood was collected from cardiac puncture, in tubes containing anticoagulant (sodium fluoride). The plasma was separated by centrifugation. The levels of plasmatic total protein, albumin, uric acid, and total cholesterol were determined on an automated biochemical analyzer.

\section{Organ properties}

After collecting blood, one bird per repetition was euthanized by cervical dislocation. The small intestine, liver, pancreas, gizzard, crest, dewlap, oviduct, and abdominal fat were collected and expressed in terms of relative weight per $100 \mathrm{~g}$ of body weight. The length of small intestine and oviduct were measured. The birds were weighed on a precision scale. The measurement of the length of the intestines was performed from the initial portion of the duodenum to the rectum, and that of the oviduct, from the infundibulum to the vagina. 


\section{Statistical analysis}

The experiment was designed as a $2 \times 4$ factorial arrangement and the data were analyzed using the $\mathrm{R}$ program (version 2020) in the model as follows:

$$
\mathrm{Y}_{\mathrm{ijk}}=\mu+\mathrm{a}_{\mathrm{i}}+\mathrm{b}_{\mathrm{j}}+(\mathrm{ab})_{\mathrm{ij}}+\varepsilon_{\mathrm{ijk}},
$$

in which $\mathrm{y}_{\mathrm{ijk}}=$ value observed in the rearing system $\mathrm{i}(\mathrm{i}=1$, 2), level $\mathrm{j}(\mathrm{j}=1,2,3,4)$, and repetition $\mathrm{k}(\mathrm{k}=1,2,3, \ldots, 5) ; \mu$ = overall mean of the experiment; $a_{i}=$ fixed effect of the system $i(i=1,2) ; b_{j}=$ fixed effect of the level $j(j=1,2,3,4)$; $(a b)_{i j}=$ fixed effect of the interaction between system $i(i=1$, 2) and level $\mathrm{j}(\mathrm{j}=1,2,3,4)$; and $\varepsilon_{\mathrm{ijk}}=$ random error in the system $\mathrm{i}(\mathrm{i}=1,2)$, level $\mathrm{j}(\mathrm{j}=1,2,3,4)$, and repetition $\mathrm{k}(\mathrm{k}=$ $1,2,3, \ldots, 5)$.

Data were submitted to analysis of variance. The significance of difference among the treatments was assessed using the Scott Knott test. The significance adopted was p-value $<0.05$.

\section{RESULTS}

\section{The effect of rearing system}

The small intestine length was not affected by the rearing system (Table 2). Compared to cage system, birds reared on the floor system showed greater small intestine $(\mathrm{p}=0.0223$, Table 2$)$, greater oviduct $(\mathrm{p}<0.001$, Table 3$)$ and lower liver $(\mathrm{p}<0.001$, Table 2$)$ and pancreas $(\mathrm{p}=0.0082)$ relative weights (Table 2). The oviduct length, the percentage of abdominal fat, the relative weight of crest and dewlap were not affected by the rearing system (Table 3 ). The blood parameters were similar in birds reared in cage and floor system (Table 4).

\section{The effect of crude protein content}

The small intestine length was negatively affected using 140 and $180 \mathrm{~g} / \mathrm{kg}$ of CP ( $\mathrm{p}=0.0127$, Table 2). Relative weight of small intestine was lower in birds fed 150 and $180 \mathrm{~g} / \mathrm{kg}$ of $\mathrm{CP}(\mathrm{p}=0.0049$, Table 2$)$. The CP did not affect the relative weight of liver, and pancreas (Table 2), oviduct length, relative weight of oviduct (Table 3) and serum albumin content (Table 4).

The statistical interaction effect for the studied factors There were significant interactions between protein levels and raising system for the relative weight of gizzard $(p=0.0386$, Table 2$)$, crest ( $p=0.0481$, Table 3$)$ and dewlap $(p=0.0067$, Table 3 ) and to serum protein $(\mathrm{p}=0.0138$, Table 4$)$, uric acid $(\mathrm{p}<0.001$, Table 4$)$ and total cholesterol $(\mathrm{p}=0.0094$, Table 4$)$. Birds reared in floor system and fed diets with 160 and 180 $\mathrm{g} / \mathrm{kg}$ CP presents lower relative gizzard weight, but birds

Table 2. The relative weight of digestive organs ( $\mathrm{g} / 100 \mathrm{~g}$ of body weight) and small intestine length (cm) of laying hens reared different systems and fed diets with different levels of crude protein

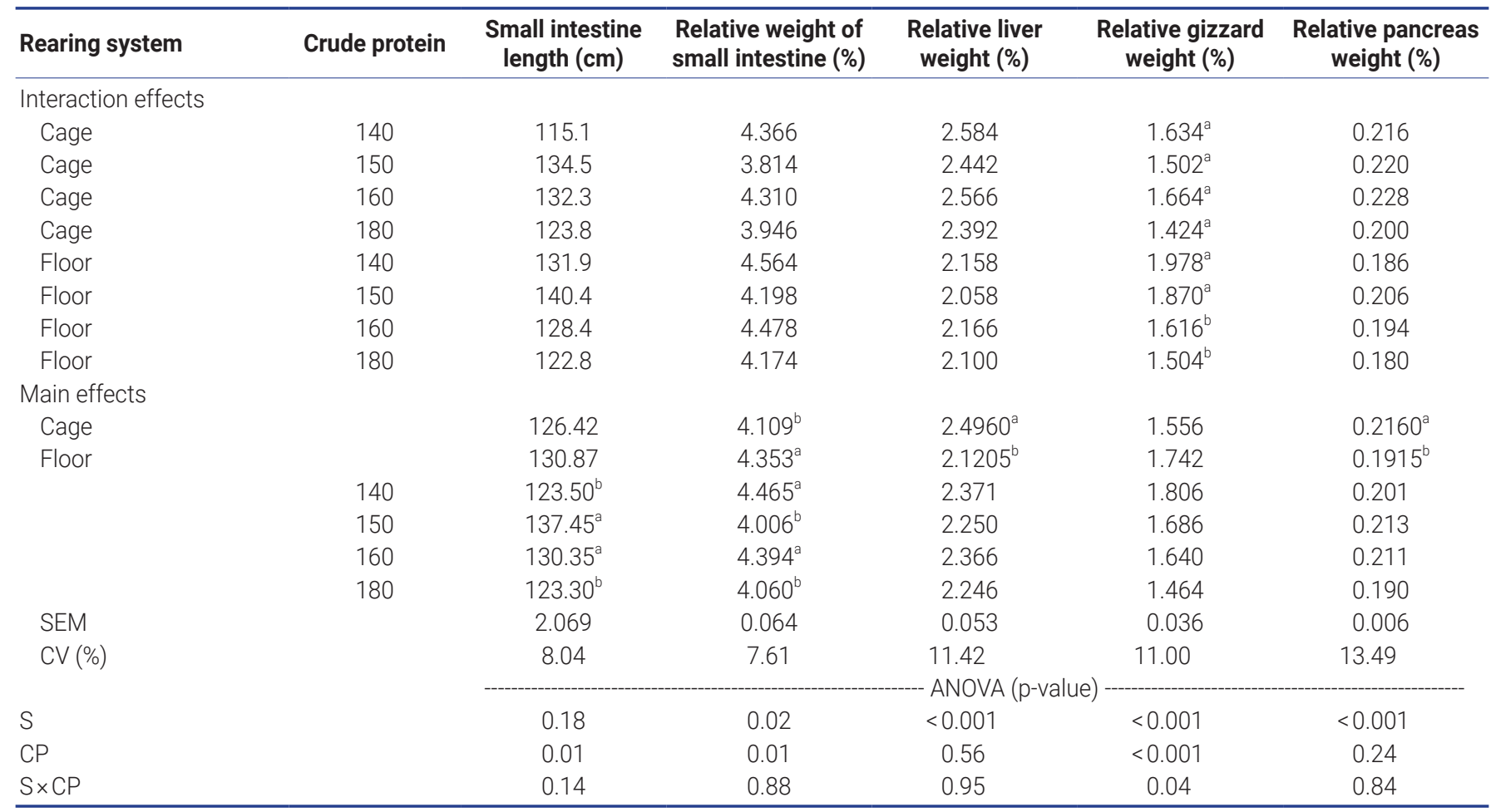

SEM, standard error of the mean; ANOVA, analysis of variance; CV, coefficient of variation; S, rearing system; CP, crude protein.

a,b Means within a column-subgroup with no common superscript letters are significantly different at $p<0.05$ by Scott Knott test. 
Table 3. The relative weight of reproductive organs ( $\mathrm{g} / 100 \mathrm{~g}$ of body weight) and oviduct length (cm) of laying hens reared different systems and fed diets with different levels of crude protein

\begin{tabular}{|c|c|c|c|c|c|c|}
\hline Rearing system & Crude protein & $\begin{array}{l}\text { Oviduct length } \\
(\mathrm{cm})\end{array}$ & $\begin{array}{c}\text { Relative oviduct } \\
\text { weight (\%) }\end{array}$ & $\begin{array}{l}\text { Relative weight of } \\
\text { abdominal fat (\%) }\end{array}$ & $\begin{array}{c}\text { Relative crest } \\
\text { weight (\%) }\end{array}$ & $\begin{array}{c}\text { Relative weight of } \\
\text { dewlap (\%) }\end{array}$ \\
\hline \multicolumn{7}{|l|}{ Interaction effects } \\
\hline Cage & 140 & 61.6 & 3.530 & 2.418 & $0.3000^{\mathrm{a}}$ & $0.1867^{\mathrm{a}}$ \\
\hline Cage & 150 & 60.4 & 3.286 & 2.050 & $0.2275^{b}$ & $0.1520^{b}$ \\
\hline Cage & 160 & 59.4 & 3.356 & 2.236 & $0.2480^{b}$ & $0.1760^{a}$ \\
\hline Cage & 180 & 58.9 & 3.146 & 1.902 & $0.1900^{b}$ & $0.1560^{b}$ \\
\hline Floor & 160 & 53.8 & 4.378 & 2.314 & $0.2125^{b}$ & $0.1140^{b}$ \\
\hline Floor & 180 & 60.1 & 4.270 & 2.168 & $0.1850^{b}$ & $0.1060^{b}$ \\
\hline \multicolumn{7}{|l|}{ Main effects } \\
\hline Cage & & 60.075 & $3.3295^{b}$ & 2.1515 & 0.2414 & 0.1677 \\
\hline Floor & & 57.025 & $4.1780^{\mathrm{a}}$ & 2.0780 & 0.2219 & 0.1291 \\
\hline SEM & & 1.252 & 0.085 & 0.086 & 0.007 & 0.013 \\
\hline CV (\%) & & 10.69 & 11.35 & 20.32 & 15.41 & 13.55 \\
\hline S & & 0.13 & $<0.001$ & 0.59 & 0.11 & $<0.001$ \\
\hline $\mathrm{CP}$ & & 0.41 & 0.62 & 0.51 & $<0.001$ & 0.01 \\
\hline $\mathrm{S} \times \mathrm{CP}$ & & 0.50 & 0.41 & 0.19 & 0.05 & $<0.001$ \\
\hline
\end{tabular}

SEM, standard error of the mean; CV, coefficient of variation; ANOVA, analysis of variance; S, rearing system; CP, crude protein.

$a, b$ Means within a column-subgroup with no common superscript letters are significantly different at $p<0.05$ by Scott Knott test.

Table 4. The blood parameters of laying hens reared different systems and fed diets with different levels of crude protein

\begin{tabular}{|c|c|c|c|c|c|}
\hline Rearing system & Crude protein & Serum protein $(\mathrm{g} / \mathrm{dL})$ & Albumin (g/dL) & Uric acid (mg/dL) & Total cholesterol (mg/dL) \\
\hline \multicolumn{6}{|l|}{ Interaction effects } \\
\hline Cage & 140 & $5.010^{\mathrm{a}}$ & 2.252 & $2.630^{\mathrm{b}}$ & $123.10^{\mathrm{a}}$ \\
\hline Cage & 150 & $4.336^{\mathrm{a}}$ & 2.184 & $2.932^{b}$ & $105.88^{\mathrm{a}}$ \\
\hline Cage & 160 & $4.218^{\mathrm{a}}$ & 1.968 & $3.980^{\mathrm{a}}$ & $108.32^{\mathrm{a}}$ \\
\hline Cage & 180 & $4.460^{\mathrm{a}}$ & 2.050 & $3.780^{\mathrm{a}}$ & $114.52^{\mathrm{a}}$ \\
\hline Floor & 140 & $3.928^{b}$ & 1.916 & $2.782^{\mathrm{c}}$ & $86.44^{c}$ \\
\hline Floor & 180 & $4.948^{\mathrm{a}}$ & 2.336 & $6.378^{\mathrm{a}}$ & $151.65^{\mathrm{a}}$ \\
\hline \multicolumn{6}{|l|}{ Main effects } \\
\hline Cage & & 4.506 & 2.1135 & 3.3305 & 112.95 \\
\hline \multirow[t]{2}{*}{ Floor } & & 4.667 & 2.2025 & 3.9895 & 118.96 \\
\hline & 140 & 4.469 & 2.084 & 2.706 & 104.770 \\
\hline SEM & & 0.132 & 0.069 & 0.145 & 4.612 \\
\hline $\mathrm{CV}(\%)$ & & 14.41 & 15.98 & 20.68 & 19.89 \\
\hline S & & 0.45 & 0.42 & $<0.001$ & 0.41 \\
\hline $\mathrm{CP}$ & & 0.86 & 0.85 & $<0.001$ & 0.05 \\
\hline $\mathrm{S} \times \mathrm{CP}$ & & 0.01 & 0.12 & $<0.001$ & $<0.001$ \\
\hline
\end{tabular}

SEM, standard error of the mean; CV, coefficient of variation; ANOVA, analysis of variance; S, rearing system; CP, crude protein.

${ }^{a-c}$ Means within a column-subgroup with no common superscript letters are significantly different at $p<0.05$ by Scott Knott test. 
reared in cage system showed no differences for this variable. The diet containing $140 \mathrm{~g} / \mathrm{kg} \mathrm{CP}$ resulted in the highest relative crest weight on birds reared in cage system. Birds reared in floor system and fed diets with 140 and $150 \mathrm{~g} / \mathrm{kg} \mathrm{CP}$ presented greater relative crest weight compared to other groups. For dewlap relative weight, birds on cage system showed greater values when fed diets with 140 and $160 \mathrm{~g} / \mathrm{kg} \mathrm{CP}$, and hens raised in floor had showed greater relative with diets containing 160 and $180 \mathrm{~g} / \mathrm{kg} \mathrm{CP}$.

In observation of the data presented in Table 4, the birds fed diets containing $140 \mathrm{~g} / \mathrm{kg}$ CP showed lower serum protein and lower total cholesterol when reared in floor system, while the ones reared in cage system had no effect of $\mathrm{CP}$ on both parameters. Birds reared in cage system that were fed diets with 140 and $150 \mathrm{~g} / \mathrm{kg} \mathrm{CP}$ presented lower uric acid when compared to birds fed 160 and $180 \mathrm{~g} / \mathrm{kg} \mathrm{CP}$ rations. The group of birds reared in floor system fed $180 \mathrm{~g} / \mathrm{kg} \mathrm{CP}$ had greater uric acid, compared to the hens that received $160 \mathrm{~g} / \mathrm{kg} \mathrm{CP}$ and the lowest values were observed for the ones fed 140 and $150 \mathrm{~g} / \mathrm{kg} \mathrm{CP}$.

\section{DISCUSSION}

The changing of rearing system from cage to floor system is a trend aimed at improving hens' welfare. In the present study verified that laying hens reared in floor system did not show any difference in blood parameters compared to those birds reared in cage system. Blood parameters provide information on a bird's metabolism, stress response and consequently indicate effects that can affect the performance results. It was confirmed that stress can cause elevations in blood levels of corticosterone, glucose, cholesterol, and high density lipoprotein, whereas triglycerides levels were reduced by adrenocorticotrophic hormone (ACTH) treatment [19]. Negative correlations between cholesterol content in serum and egg can indicate that eggs from hens reared in cages contained significantly more cholesterol than eggs laid by hens reared in floor pens [20]. In this context, the manipulation of serum cholesterol could result in different content in the eggs. The housing system affects the concentration of cholesterol where lower values were found on litter in comparation to cage system [21]. However, in the present experiment, the total cholesterol was similar between the rearing systems (cage and floor).

The serum content of protein, albumin, uric acid, and cholesterol are affected by age [22], pathological factors [23] and dietary additives [24]. In this experiment, a significant interaction between the dietary $\mathrm{CP}$ and rearing system on serum protein, uric acid, and total cholesterol of hens was observed. Exception made for albumin serum levels; the other blood parameters were affected by diets when birds were reared in floor system. On the other hand, only serum uric acid was affected by the dietary $\mathrm{CP}$ in birds housed in cage system. A significant interaction between the factors corresponds with the findings from Kraus et al [21] who verified that housing system, breed and age of hen affects the blood parameters with significant interaction between the factors. The birds reared in floor system presented more variation on metabolism according to dietary CP compared to birds reared in cage system. This may indicate a different demand of protein by birds in relation to housing system. Likewise, the stocking density of birds differed according to the rearing system and may contributed to differences in bird's metabolism observed.

Birds reared in the cage system and fed diets with 160 and $180 \mathrm{~g} / \mathrm{kg} \mathrm{CP}$ presented greater levels of uric acid. This response was expected because uric acid is the method of excretion of excess of dietary nitrogen. Birds reared on the floor and fed with $180 \mathrm{~g} / \mathrm{kg} \mathrm{CP}$ produced more than $200 \%$ more uric acid than those fed with $140 \mathrm{~g} / \mathrm{kg} \mathrm{CP}$. The excretion of uric acid increases when the diet contains an excess of $\mathrm{CP}$. Besides the function of nitrogen excretion, uric acid had been related to one of the most important antioxidants in birds and is linked to their longevity [25].

The relative weight of small intestine and oviduct of laying hens reared in floor pens was greater than hens reared in cages. These results are in agreement with Yang et al [26] who reported that the weight of proventriculus, gizzard, liver, spleen, duodenum, jejunum, ileum, cecum, and rectum of free-range birds was higher than those of cagereared. Some researchers determined that organ weights were heavier in hens ranged on pasture and related that the pasture intake increased digestive organ weight [27], and fiber intake [28]. In the present study the birds were reared in floor with rice hulls as a litter, however, they did not had access to the pasture.

On the other hand, it is noticed that the floor system resulted in lower relative liver and pancreas weights of birds. These organs are responsible for enzyme production among other functions and are affected principally by diets. The liver weight has been related to stress response in laying hens [19]. Some authors verified that dry weight, moisture, protein, fat, carbohydrate, and ash contents of liver were all increased in laying hens under stress mediated by continuous infusion of ACTH [19]. The higher liver weight can indicate a metabolic disorder called fatty liver haemorrhagic syndrome (FLHS). Factors associated with husbandry practices in different production systems, such as restricted movement, increased production and temperature variations, influence hepatic lipid metabolism and predispose hens to FLHS [29].

The oviduct length, the percentage of abdominal fat, the relative crest and dewlap weights were not affected by the rearing system. These characteristics are related to reproductive performance of laying hens. Because of the stress response, 
the weight of the oviduct of laying hens can be reduced $[19,30]$. According to Wang et al [31] the elevated corticosterone levels in response to stressors may be associated with suppressed reproduction in laying hens via a possible perturbation of the hypothalamic-pituitary-gonadal axis. Therefore, based in reproductive characteristics, the birds did not present symptoms of stress according to the rearing system studied.

The reduction of dietary $\mathrm{CP}$ with amino acids supplementation aims to minimize the pollution with nitrogen products from poultry excretion [32]. Furthermore, the reduction of CP with amino acid supplementation improves the hens' egg production, the small intestine villus height and promoting beneficial effects of faecal microflora [33].

In the present study, the small intestine length and relative weight of small intestine were affected by dietary CP. Both low and greater levels of $\mathrm{CP}$ negatively affected the intestine development. The other parameters evaluated were not affected by the dietary $\mathrm{CP}$ as an isolated factor, indicating that the reduction of dietary CP until $140 \mathrm{~g} / \mathrm{kg}$ with amino acids supplementation can be used as a criterion for diet formulations.

Significant interactions were observed between protein level and raising system for some parameters studied (relative weights of gizzard crest and dewlap and for serum protein, uric acid, and total cholesterol content). The relative gizzard weight of birds reared in cage system was not affected by $\mathrm{CP}$ but as the dietetic CP content increased in birds reared in floor system there was a decrease of relative gizzard weight. The gizzard plays an important function in digestive process of diets, so according to Svihus et al [34] there are a renewed interest in nutritional effects in diets that can stimulate the development and function of the gizzard. Freitas et al [28] concluded that the neutral detergent fiber reduced gizzard weight of hens. In the present study, the reduction of CP was beneficial to gizzard development, however, more studies are required to elucidate these findings.

The reduction of CP until $140 \mathrm{~g} / \mathrm{kg} \mathrm{CP}$ and $150 \mathrm{~g} / \mathrm{kg}$ to laying hens reared in cage and floor system, respectively, resulted in the highest relative crest weight. Birds on cage system showed greater relative dewlap weight when fed with 140 and $160 \mathrm{~g} / \mathrm{kg}$ CP. Birds on floor system showed greater relative dewlap weight when fed diets with 160 and $180 \mathrm{~g} / \mathrm{kg}$ of CP. These sexual characteristics of laying hens could be associated with productive performance and requires further investigation.

The diets with $140 \mathrm{~g} / \mathrm{kg}$ CP resulted in lower serum protein and lower total cholesterol content in birds reared in floor system, indicating a possible CP deficiency. In contrast, birds reared in cage system showed no effect of CP on serum protein and total cholesterol. Some factors are related to cholesterol metabolism in hen, as different levels of methionine throughout the day [35] and fiber intake [36], however the hypocholesterolemic effect associated to the protein is unclear.

\section{IMPLICATIONS}

This study demonstrate that the dietary protein level can be reduced up to $140 \mathrm{~g} / \mathrm{kg}$ for Hisex Brown hens from 30 to 45 weeks of age, in both rearing systems, cage and floor.

\section{CONFLICT OF INTEREST}

We certify that there is no conflict of interest with any financial organization regarding the material discussed in the manuscript.

\section{FUNDING}

The authors would like to thank the Instituto Federal Goiano/ Campus Urutaí, and the Olvego Óleos Vegetais Ltda, MCassab and Ajinomoto ${ }^{\otimes}$ for financial support for this study.

\section{REFERENCES}

1. Casey-Trott TM, Guerin MT, Sandilands V, Torrey S, Widowski TM. Rearing system affects prevalence of keel-bone damage in laying hens: a longitudinal study of four consecutive flocks. Poult Sci 2017;96:2029-39. https://doi.org/10.3382/ps/pex026

2. Brantsæter M, Nordgreen J, Rodenburg TB, Tahamtani FM, Popova A, Janczak AM. Exposure to increased environmental complexity during rearing reduces fearfulness and increases use of three-dimensional space in laying hens (Gallus gallus domesticus). Front Vet Sci 2016;3:14. https:// doi.org/10.3389/fvets.2016.00014

3. Netto DA, Lima HJD, Alves JR, Morais BC, Rosa MS, Bittencourt TM. Production of laying hens in different rearing systems under hot weather. Acta Sci 2018;40:e37677. [Epub February 15]. https://doi.org/10.4025/actascianimsci.v40i1. 37677

4. Singh R, Cheng KM, Silversides FG. Production performance and egg quality of four strains of laying hens kept in conventional cages and floor pens. Poult Sci 2009;88:256-64. https:// doi.org/10.3382/ps.2008-00237

5. Radu-Rusu RM, Usturoi MG, Leahu A, Amariei S, RaduRusu CG, Vacaru-Opriş I. Chemical features, cholesterol and energy content of table hen eggs from conventional and alternative farming systems. S Afr J Anim Sci 2014;44:3342. https://doi.org/10.4314/sajas.v44i1.5

6. Galic A, Filipovic D, Janjecic Z, et al. Physical and mechanical characteristics of Hisex Brown hen eggs from three different housing systems. S Afr J Anim Sci 2019;49:468-76. https:// doi.org/10.4314/sajas.v49i3.7

7. Heflin LE, Malheiros R, Anderson KE, Johnson LK, Raatz 
SK. Mineral content of eggs differs with hen strain, age, and rearing environment. Poult Sci 2018;97:1605-13. https://doi. org/10.3382/ps/pey025

8. Engel JM, Widowski TM, Tilbrook AJ, Butler KL, Hemsworth $\mathrm{PH}$. The effects of floor space and nest box access on the physiology and behavior of caged laying hens. Poult Sci 2018;98:533-47. https://doi.org/10.3382/ps/pey378

9. Bezerra RM, Costa FGP, Givisiez PEN, Goulart CC, Santos RA, Lima MR. Glutamic acid supplementation on low protein diets for laying hens. Acta Sci 2015;37:129-34. https://doi. org/10.4025/actascianimsci.v37i2.25911

10.Englmaierová $\mathrm{M}$, Tůmová $\mathrm{E}$, Charvátová $\mathrm{V}$, Skřrivan $\mathrm{M}$. Effects of laying hens housing system on laying performance, egg quality characteristics, and egg microbial contamination. Czech J Anim Sci 2014;59:345-52.

11.de Almeida Brainer MM, Rabello CBV, dos Santos MJB, et al. Crude protein requirements of free-range laying hens. Anim Prod Sci 2015;56:1622-8. https://doi.org/10.1071/ AN14890

12.Tufarelli V, Baghban-Kanani P, Azimi-Youvalari S, et al. Effects of horsetail (Equisetum arvense) and spirulina (Spirulina platensis) dietary supplementation on laying hens productivity and oxidative status. Animals 2012;11: 335. https://doi.org/10.3390/ani11020335

13. Bozakova NA, Sotirov LK, Sasakova N, Lakticova KV. Welfare improvement in laying hens during the hot period under a semi-open rearing system through dietary arginine and vitamin C supplementation. Bulg J Vet Med 2015;18:21626. https://doi.org/10.15547/bjvm.869

14. Kang S, Da-Hye K, Lee S, et al. An acute, rather than progressive, increase in temperature-humidity index has severe effects on mortality in laying hens. Front Vet Sci 2020;7:568093. https://doi.org/10.3389/fvets.2020.568093

15. Gonzalez FHD, Scheffer JFS. Blood profile: clinical, metabolic and nutritional analysis tools. In: Gonzalez FHD, Compos R, editors. Anais do ${ }^{\circ}$ Simpósio de Patologia Clínica Veterinária da Regiao Sul do Brazil. Porto Alegre-RS, Brazil: Gráfica da Universidade Federal do Rio Grande do Sul; 2003. pp. 73-88.

16.De Vylder J, Dewulf J, Van Hoorebeke S, et al. Horizontal transmission of Salmonella Enteritidis in groups of experimentally infected laying hens housed in different housing systems. Poult Sci 2011;90:1391-6. https://doi.org/10.3382/ ps.2010-00944

17.Parisi MA, Northcutt JK, Smith DP, Steinberg EL, Dawson PL. Microbiological contamination of shell eggs produced in conventional and free-range housing systems. Food Control 2015;47:161-5. https://doi.org/10.1016/j.foodcont.2014.06. 038

18. Rostagno HS, Albino LFT, Donzele JL, et al. Brazilian tables for poultry and swine. 3rd ed. Viçosa, MG, Brazil: Editora UFV; 2011.
19. Mumma JO, Thaxton JP, Vizzier-Thaxton Y, Dodson WL. Physiological stress in laying hens. Poult Sci 2006;85:761-9. https://doi.org/10.1093/ps/85.4.761

20. Basmacioğlu H, Ergül M. Research on the factors affecting cholesterol content and some other characteristics of eggs in laying hens the effects of genotype and rearing system. Turk J Vet Anim Sci 2005;29:157-64.

21. Kraus A, Zita L, Krunt O, Härtlová H, Chmelíková E. Determination of selected biochemical parameters in blood serum and egg quality of Czech and Slovak native hens depending on the housing system and hen age. Poult Sci 2021;100:114253. https://doi.org/10.1016/j.psj.2020.10.039

22.Silva PRL, Freitas Neto OC, Laurentiz AC, Junqueira OM, Fagliari JJ. Blood serum components and serum protein test of Hybro-PG broilers of different ages. Braz J Poult Sci 2007; 9:229-32. https://doi.org/10.1590/S1516-635X2007000400004

23. Lloyd S, Gibson JS. Haematology and biochemistry in healthy young pheasants and red-legged partridges and effects of spironucleosis on these parameters. Avian Pathol 2006;35: 335-40. https://doi.org/10.1080/03079450600821794

24. Alkhalf A, Alhaj M, Al-Homidan I. Influence of probiotic supplementation on blood parameters and growth performance in broiler chickens. Saudi J Biol Sci 2010;17:219-25. https://doi.org/10.1016/j.sjbs.2010.04.005

25.Simoyi MF, Van Dyke K, Klandorf H. Manipulation of plasma uric acid in broiler chicks and its effect on leukocyte oxidative activity. Am J Physiol Regul Integr Comp Physiol 2002;282: R791-6. https://doi.org/10.1152/ajpregu.00437.2001

26. Yang HM, Yang Z, Wang W, et al. Effects of different housing systems on visceral organs, serum biochemical proportions, immune performance and egg quality of laying hens. Eur Poult Sci 2014;78L48. https://doi.org/10.1399/eps.2014.48

27.Iqbal Z, Roberts J, Perez-Maldonado RA, Goodarzi Boroojeni F, Swick RA, Ruhnke I. Pasture, multi-enzymes, benzoic acid and essential oils positively influence performance, intestinal organ weight and egg quality in free-range laying hens. Br Poult Sci 2018;59:180-9. https://doi.org/10.1080/ 00071668.2017.1403566

28. Freitas ER, Braz NM, Watanabe PH, Cruz CEB, Nascimento GAJ, Bezerra RM. Fiber level for laying hens during the growing phase. Ciênc Agrotec 2014;38:188-98. https://doi. org/10.1590/S1413-70542014000200010

29. Shini A, Shini S, Bryden WL. Fatty liver haemorrhagic syndrome occurrence in laying hens: impact of production system. Avian Pathol 2019;48:25-34. https://doi.org/10.1080/ 03079457.2018.1538550

30. Attia YA, Abd El AEHE, Abedalla AA, et al. Laying performance, digestibility and plasma hormones in laying hens exposed to chronic heat stress as affected by betaine, vitamin C, and/or vitamin E supplementation. SpringerPlus 2016;5: 1619. https://doi.org/10.1186/s40064-016-3304-0

31.Wang XJ, Liu L, Zhao JP, Jiao HC, Lin H. Stress impairs the 
reproduction of laying hens: an involvement of energy. World's Poult Sci J 2017;73:845-56. https://doi.org/10.1017/s0043 933917000794

32. Alagawany M, Abd El-Hack ME, Arif M, Ashour EA. Individual and combined effects of crude protein, methionine, and probiotic levels on laying hen productive performance and nitrogen pollution in the manure. Environ Sci Pollut Res Int 2016;23:22906-13. https://doi.org/10.1007/s11356016-7511-6

33. Tenesa M, Loh TC, Foo HL, Samsudin AA, Mohamad R, Raha AR. Effects of feeding different levels of low crude protein diets with different levels of amino acids supplementation on layer hen performance. Pertanika J Trop Agric Sci
2016;39:543-55.

34. Svihus B. The gizzard: function, influence of diet structure and effects on nutrient availability. Worlds Poult Sci J 2011; 67:207-24. https://doi.org/10.1017/s0043933911000249

35.Liu Y, Wan D, Zhou X, et al. Effects of dynamic feeding lowand high-methionine diets on the variation of glucose and lipid metabolism-related genes in the liver of laying hens. Poult Sci 2019;98:2231-40. https://doi.org/10.3382/ps/pey589

36.Laudadio V, Ceci E, Lastella NMB, Tufarelli V. Effect of feeding low-fiber fraction of air-classified sunflower (Helianthus annus L.) meal on laying hen productive performance and egg yolk cholesterol. Poult Sci 2014;93:2864-9. https://doi. org/10.3382/ps.2014-04204 